\title{
Land Tenure System and Its Effect on Productivity, Profitability and Efficiency of Boro Rice Production in Northern Part of Bangladesh
}

\author{
Nazmoon Naher Moon ${ }^{1, a}$, Md. Emran Hossain ${ }^{1, b, *}$, Md. Akhtaruzzaman Khan ${ }^{1, c}$, \\ Mohammad Ataur Rahman ${ }^{1, \mathrm{~d}}$, Sourav Mohan Saha ${ }^{1, \mathrm{e}}$ \\ ${ }^{1}$ Department of Agricultural Finance and Banking, Faculty of Agricultural Economics and Rural Sociology, Bangladesh Agricultural \\ University, Mymensingh-2202, Bangladesh \\ *Corresponding author
}

\section{A R T I C L E I N F O} A B S T R A C T

Research Article

Received : 05/07/2020

Accepted : 11/10/2020

Keywords:

Land tenure system

Efficiency difference

Marshallian inefficiency

Stochastic production function

Bangladesh

\begin{abstract}
Access to land in Bangladesh is governed by the state rule but informal tenure arrangement is existing all over the country. Land productivity differs with the contractual arrangement between landlord and tenant. Inefficiency may arise due to sharecropping which is known as Marshallian inefficiency. This study investigated the productivity the productivity, profitability and efficiency of different tenure arrangement of Boro rice cultivation selecting 120 farmers from Rangpur district of Bangladesh. The stochastic frontier production function was employed to determine the efficiency. Moreover, t-test was performed to see whether any significant difference exist among tenure categories in terms of productivity, profitability and efficiency. Four types of tenure arrangements were identified as cash tenant, fifty-fifty input-output sharing arrangement, only output sharing arrangement and owner farmers. Result revealed that productivity and profitability was higher for owner and cash tenant compared to others. Significant productivity and profitability difference were found between owner farmers and cash tenants versus sharecroppers. Result also found that inefficiency level was significantly high for fifty-fifty input-output share tenant and only output share tenant compared to cash tenant and owner operator implying that Marshallian inefficiency exist due to sharecropping system in the Boro rice production.
\end{abstract}

anazmoonnaharmoon@yahoo.com c-azkhan13@yahoo.com e@souravmohansaha@gmail.com

\section{(iD) https://orcid.org/0000-0002-7226-3614 (iD) https://orcid.org/0000-0002-2968-0375} (iD) https://orcid.org/0000-0003-4494-9974 bemranaerd@gmail.com (iD) https://orcid.org/0000-0001-6882-0177 d@marahman@bau.edu.bd (i) https://orcid.org/0000-0003-0683-202X

(c) $)$ () (9) This work is licensed under Creative Commons Attribution 4.0 International License

\section{Introduction}

Land tenure systems affect agricultural productivity by influencing the efficient use of inputs and the adoption of modern technology. Land tenure and property rights affect the application of technologies for agricultural and natural resource management (Islam, 2012). Secured property rights give sufficient incentives to farmers to increase their efficiencies in terms of productivity and ensure environmental sustainability (Tenaw et al., 2009). It is natural that without secured property rights farmers do not feel emotional attachment to the land they cultivate, do not invest in land development and will not use inputs efficiently (Tenaw et al., 2009). Therefore, the distribution of land and the land tenure system may significantly affect farm household land management which, in turn, influences land productivity (Aryal, 2010). If property rights are absent and if land tenancy is insecure, farmers do not care much about the land use and though concentrate on short terms profit-maximizing at the cost of accelerating the degradation of land (Ahmed, 2011).
Tenant system in agricultural farm is common in the rural area of Bangladesh from the very beginning of the Zamindari system. As a result of the East Bengal State Acquisition and Tenancy Act 1950, the class of pure rent recipients was eliminated as soon as the zamindari system was abolished (Jabbar, 1978). But the tenancy system remained unchanged in the rural economy. The proportion of area under tenancy is observed to increase from about $17 \%$ of the operated area in $1983-84$ to about $29.36 \%$. Out of $29.36 \%$ tenant households, $1.60 \%$ is in urban areas and $27.76 \%$ are in rural areas (Agriculture Census, 2008). This change may be due to the rapid rural-urban migration along with the increase of absentee landowners and the abandonment of some farms in favor of taking up rural non-farm occupations. A substantial proportion of land in rural areas is owned by absentee landlords, most of whom reside in urban areas and they lease their land under sharecropping arrangements (Uddin and Haque, 2009). 
Marshall regarded sharecropping as an inefficient form of contracting which results in the persistence of low agricultural yields. Otsuka and Hayami (1988), Singh (1989), Hayami and Otsuka (1993) and Otsuka (2007) have claimed that the empirical evidence on Marshallian inefficiency, meaning a systematic downward bias in input intensity and productivity on sharecropped land than owned land, is far from universal. Therefore, Marshallian inefficiency was significant in the case of tenant farmers.

Households that do not have sufficient resources to operate production process may rent out land under various tenancy arrangements (Taslim and Ahmed, 1992). Some tenure arrangements are common in rural areas of Bangladesh. These are 'only output share' tenant, 'fiftyfifty input-output share' tenant, 'cash tenant', and 'owner farmer'. Among them the most dominant tenancy arrangement in Bangladesh is output share tenancy followed by cash tenant (Taslim and Ahmed, 1992). In only output share tenure system, landlord does not give any input and they take one-third of the return. In fifty-fifty input-output share tenant, landlord bear half the amount of cost of fertilizer, irrigation, pesticide/insecticide, seed and tractor but do not bear any labor cost and get half the amount of total return and they have acute supervision on land use to ensure the tenant do not cultivate the land too frequently. In cash tenant system, landlord takes a fixed amount of cash as per the yearly basis from the tenant for his/her land cultivation without bearing any input cost and does not pay any attention regarding the frequency of land use. The cash tenants and output share tenant who lease land for farming also bear all or most managerial functions including operation of all production inputs. These tenurial arrangements are particularly enchanting among households who do not have enough active family labors available for farming activities or who cannot afford all essential inputs for cultivation (Taslim and Ahmed, 1992). Owner farmers are cultivating their own lands by themselves, they do not rent in or rent out any land and all return for himself/herself.

Several studies have measured the profitability and efficiency of different sharing arrangements and reported their results. Some studies have noted that owner or landlord farmers are more efficient than owner-cumtenants and tenants (Ali, 2000; Zaman, 2002; Bhownick et al., 2003; Mondal, 2005; Khan, 2008; Ahmed, 2011). In some cases, obstacles and the impact of socio-demographic factors on the tenure system are also reported (Reiersen, 2001; Marara, 2007; Tenaw et al., 2009; Rahman, 2010). Ahmed (2011), Nasrin (2011) and Arindam and Kuri (2012) found the land type, irrigation facilities and contractual choice have a significant effect on tenure arrangement because both the tenant owner are concerned about production uncertainty. Nevertheless, based on this background discussion, yet an ongoing controversy is very common on different sharing arrangement and its on productivity and efficiency. Consequently, this paper has made an effort to response "does land tenancy effect on sharecropper's efficiency?" However, there is no study found regarding the land tenure system in the northern part of Bangladesh where Boro rice is the main agricultural crop and most of the peoples' livelihood is very much rely on Boro rice as their main source of income. Therefore, this study has tried to evaluate the efficiency of different tenure categories of land tenure system in Bangladesh in terms of Boro rice farmers, and also assessed the effect of land tenure system on productivity and profitability.

\section{Materials and Methods}

Study Area, Sampling Technique and Data Collection

Rice is the main agricultural crop in Bangladesh which is cultivated all over the country. But, soil fertility and climatic condition of northern part is favorable for rice production. Rangpur, Dinajpur and Rajshahi is the main producing areas of Bangladesh. Initially, Rangpur district was selected purposively where total Boro rice production was 19575819 MT in $2017-18$ which is $3.15 \%$ of country's production (BBS, 2018). Secondly, Mithapukur Upazila (Sub-district) of Rangpur district was selected because most of the farming practice takes place under sharing arrangements and the Boro rice is one of the major crops in these areas. Finally, a total of 120 farmers were selected through a simple random sampling technique of which 20 farmers were fifty-fifty input-output share tenant, 20 were only outputs share tenant, 40 cash tenant and 40 farmers cultivate their own land. The data was collected by face to face interviews of the respondents using a prescribed interview schedule during late January 2018. The questionnaire was pretested by interviewing 5 farmers randomly and modifications, additions, deductions were taking place as per need. Before starting the interview, a brief introduction about the researcher and the purpose of the study was given to the respondents. After completion of each interview, the questionnaire was scrutinized to make sure each data had been appropriately inserted.

\section{Analytical Technique}

In this paper, both descriptive and econometric analyses were used to fulfill the objectives. Initially, the socioeconomic characteristics of the selected respondents was measured. Then farm's productivity and profitability was calculated as per hectare basis. Finally, the efficiency of different tenure categories was estimated.

\section{Profitability Analysis}

The following algebraic equation was used to assess the profitability of Boro rice production.

$$
\pi=\mathrm{P}_{\mathrm{F}} \mathrm{Q}_{\mathrm{F}}+\mathrm{P}_{\mathrm{S}} \mathrm{Q}_{\mathrm{S}}-\Sigma\left(\mathrm{P}_{\mathrm{xi}} \cdot \mathrm{X}_{\mathrm{i}}\right)-\mathrm{TFC}
$$

Where, $\pi=$ Profit per hectare of Boro rice production (Tk/ha), $\mathrm{P}_{\mathrm{F}}=$ Per unit price of Boro paddy, $\mathrm{Q}_{\mathrm{F}}=$ quantity of Boro paddy (mound/ha), $\mathrm{P}_{\mathrm{S}}=$ per unit price of Boro straw $(\mathrm{Tk} / \mathrm{ha}), \mathrm{Q}_{\mathrm{s}}=$ quantity of Boro straw (mound/ha), $\mathrm{P}_{\mathrm{xi}}=$ per unit price of $\mathrm{i}$-th (variable) inputs used for Boro rice production, $\mathrm{i}=1,2,3 \ldots \ldots, \mathrm{n}$ and $\mathrm{TFC}=$ total fixed cost involved in producing Boro rice.

\section{Efficiency analysis}

Farrell's article on efficiency measurement led to the development of several approaches to efficiency and productivity analysis (Farrell, 1957). The Stochastic Frontier Analysis (SFA) and Data Envelopment Analysis (DEA) are the two principal methods to measure farm efficiency. As noted by Coelli et at. (1998), the stochastic frontier is considered more appropriate than DEA in 
agricultural applications, especially in developing countries, where the data are likely to be heavily influenced by the measurement errors and the effects of weather conditions, diseases, etc. Thus following Aigner et al (1977) and Meeusen and van den Broeck (1977), the stochastic frontier production with two error terms can be modeled as:

$$
Y_{i}=f\left(X_{i}, \beta\right) \exp \left(V_{i}-U_{i}\right)
$$

Where $Y_{i}$ is the production of the $i$-th farm ( $\mathrm{i}=1,2$, $3, . . n) ; X_{i}$ is a $(1 \times k)$ vector of functions of input quantities applied by the $\mathrm{i}$-th farm; $\beta$ is a $(\mathrm{k} \times \mathrm{l})$ vector of unknown parameters to be estimated; $\mathrm{V}_{\mathrm{i}} \mathrm{s}$ are random variables assumed to be independently and identically distributed ( $\mathrm{N}$ $(0, \delta 2))$ and independent of $\mathrm{U}_{\mathrm{i}} \mathrm{s}$ and the $\mathrm{U}_{\mathrm{i}} \mathrm{s}$ are nonnegative random variables, associated with technical inefficiency in production assumed to be independently and identically distributed. The first error component $\mathrm{V}$ is intended to capture the effects of random shocks outside the farmer's control, measurement error and other statistical noise and the second error component $U$ is intended to capture the effects of technical inefficiency. Following Battese and Coelli (1995), the technical inefficiency effects, Ui in equation (1) can be expressed as:

$$
\mathrm{U}_{\mathrm{i}}=\mathrm{Z}_{\mathrm{i}} \delta+\mathrm{W}_{\mathrm{i}}
$$

Where $\mathrm{W}$, are random variables, defined by the normal distribution with zero mean and variance $\sigma^{2} u$. $Z_{\mathrm{i}}$ is a vector of farm-specific variables associated with technical inefficiency and $\delta$ is a $(\mathrm{m} \times 1)$ vector of unknown parameters to be estimated.

The technical efficiency of the i-th sample farm, denoted by TE; is given by:

$$
\mathrm{TE}_{\mathrm{i}}=\exp \left(-\mathrm{U}_{\mathrm{i}}\right)=\mathrm{Y}_{\mathrm{i}} / \mathrm{f}\left(\mathrm{X}_{\mathrm{i}} \beta\right) \exp \left(\mathrm{V}_{\mathrm{i}}\right)=\mathrm{Y}_{\mathrm{i}} / \mathrm{Y}_{\mathrm{i}^{*}}
$$

Where $Y_{i^{*}}=f\left(X_{1} \beta,\right) \exp \left(V_{i}\right)$ is the farm-specific stochastic frontier. If $\mathrm{Y}_{\mathrm{i}}$ is equal to $\mathrm{Y}_{\mathrm{i}^{*}}$ then $\mathrm{TE}_{\mathrm{i}}=1$, reflects $100 \%$ efficiency. The difference between $Y_{i}$, and $Y_{i^{*}}$ is embedded in $\mathrm{U}_{\mathrm{i}}$. If $\mathrm{U}_{\mathrm{i}}=0$, implying that production lies on the stochastic frontier, the farm obtains its maximum attainable output given its level of input. If $\mathrm{U}_{\mathrm{i}}<0$, production lies below the frontier-an indication of inefficiency.

The maximum likelihood estimate (MLE) of the parameters of the model defined by equations (1) and (2) and the generation of farm-specific TE defined by (3) is estimated. The efficiencies are estimated using a predictor that is based on the conditional expectation of exp (-U) (Battese and Coelli, 1993; Coelli, 1994). In the process, the variance parameters $\sigma^{2} \mathrm{u}$, and $\sigma^{2} \mathrm{v}$, are expressed in terms of the parameterization:

$$
\begin{aligned}
& \sigma^{2}=\left(\sigma^{2} u+\sigma^{2} v\right) \\
& \text { and } \\
& \gamma=\left(\sigma^{2} u / \sigma^{2}\right)
\end{aligned}
$$

The value of $\gamma$ ranges from 0 to 1 with values close to 1 indicating that random component of the inefficiency effects makes a significant contribution to the analysis of the production system (Coelli and Battese, 1996).
Cobb-Douglas specification was found better fit than the translog, therefore Cobb-Douglas was used. The stochastic production function for the sample Boro rice growers was specified as:

$$
\ln \mathrm{Y}=\beta_{\mathrm{o}}+\beta_{1} \ln \mathrm{X}_{1}+\ldots .+\beta_{9} \ln \mathrm{X}_{9}+\mathrm{V}_{\mathrm{i}}-\mathrm{U}_{\mathrm{i}}
$$

Where, $\ln =$ natural logarithm, $\mathrm{Y}=$ observed farm output (mound/ha), $\mathrm{X}_{1}$ =human labour (man-days/ha), $\mathrm{X}_{2}$ $=\operatorname{seed}(\mathrm{kg} / \mathrm{ha}), X_{3}=$ urea $(\mathrm{Kg} / \mathrm{ha}), X_{4}=\mathrm{TSP}(\mathrm{Kg} / \mathrm{ha}), \mathrm{X}_{5}=$ $\operatorname{MoP}(\mathrm{Kg} / \mathrm{ha}), \mathrm{X}_{6}=\operatorname{gypsum}(\mathrm{kg} / \mathrm{ha}), \mathrm{X}_{7}=$ manure $(\mathrm{Tk} . / \mathrm{ha})$, $\mathrm{X}_{8}=$ insecticide (Tk./ha), $\mathrm{X}_{9}=$ irrigation (Tk./ha), $\beta_{\mathrm{i}}=$ unknown parameters to be estimated, $V_{i}=$ random error terms, $\mathrm{U}_{\mathrm{i}}=$ inefficiency effects.

The inefficiency model was estimated jointly with the general model. Inefficiency model is composed of vector of socioeconomics variables $(\mathrm{Z})$, which was defined as:

$$
\mathrm{U}_{\mathrm{i}}=\delta_{0}+\delta_{1} \mathrm{Z}_{1}+\delta_{2} \mathrm{Z}_{2}+\delta_{3} \mathrm{Z}_{3}+\delta_{4} \mathrm{Z}_{4}+\delta_{5} \mathrm{Z}_{5}+\mathrm{W}_{\mathrm{i}}
$$

Where, $Z_{1}=$ age of the farmers (years), $Z_{2}=$ education (years of schooling), $Z_{3}=$ time duration involvement with land tenure system, $\mathrm{Z}_{4}=$ credit receiving, $\mathrm{Z}_{5}=$ extension service receiving, $\delta_{\mathrm{i}}=$ parameters of the respective technical inefficiency variable to be estimated, $(i=1,2, . .5)$, $\mathrm{W}_{\mathrm{i}}$ =unobservable random variables or classical disturbance terms.

\section{Results and Discussion}

\section{Demographic Characteristics of Selected Boro Rice Producers}

Demographic characteristics of the farmers are important for influencing the productivity, profitability and efficiency of different categories of tenant. Age distribution, level of education, occupational status, credit and extension service received by the farmers, farm size etc. were considered as important demographic characteristics.

Results revealed that the mean age of only output share, fifty-fifty input-output share, cash tenant and owner farmers were 48.1, 46.8, 51.25 and 51.15 years respectively indicated that there was no significant age difference among the different categories of tenants (Table 1). Along with age, education is considered as a vital measuring scale for understanding the attitude of farm household towards production technique. Results demonstrated that owner farmers had 10.58 years of schooling then followed by fifty-fifty input - output share tenant (6.95 years of schooling), cash tenant (6.9 years of schooling) cash tenant (6.9 years of schooling) and the only output share tenant (5.9 years of schooling). However, on an average, the years of schooling of the selected farmers were 7.58.

Highest $50 \%$ of cash tenant farmers rely only on agriculture as the main occupation since they did not have any other occupation, while the rest of the farmers are engaged in some other professions such as business, service, fish farming etc. The average percentage of farmers engaged with agriculture as a primary profession was $32 \%$ that means the majority of farmers engaged with agriculture as a secondary occupation. Twenty-five percent farmers of 'only output share tenant' received credit that was higher than other categories and on an average $21 \%$ 
farmers received credit from formal or informal source of credit. Study found that only $22.5 \%$ of owner farmers received extension service that was highest among only output share $(20 \%)$, input-output share $(15 \%)$ and cash tenant $(7.5 \%)$ categories of tenants as the owners are more educated than others so they maintain good communication with the extension officer. On average $16 \%$ farmer were received extension service. It is assumed that when the farmers received more extension service they are able to transfer their knowledge into their field thus they can make efficient use of inputs as well as other resources. So the extension service received by the farmers has an impact on the efficiency of rice production.

Time of involvement with land tenure system that is experience of the tenants with land tenure system is a vital practical feature, which normally affects the efficiency of Boro rice production. The study found that the mean experience of the farmers was 10.89 years, where the cash tenant of farmers had more experience (16.68 years) than the only output share tenant (14.35 years) and fifty-fifty inputoutput share tenant (12.55 years). It is expected that the farmers who have more experience that means who are involved with the land tenure system over a long period of time have better skills and knowledge for rice production. The average farm size was found 267.43 decimals where the mean farm size of only output share, fifty-fifty input-output share, cash tenant, owner farmer categories were 258.05, 277, 304.5 and 229.95 decimals respectively (Table 1).

\section{Profitability Measurement}

The purpose of this section was to measure the per hectare profitability of Boro rice production in the study area. Costs and returns were calculated for all tenant categories to evaluate the financial performance of Boro rice producers which is shown in Table 2 . The variable cost of Boro rice production included cost of human labour, seed, power tiller, irrigation, fertilizer, cow dung or manure, insecticides etc. Land-use considered as fixed cost because cash tenant had to pay fixed amount of cash for land leasing and other sharecroppers also had to pay landlord in the form of output for using the land and it was considered as opportunity cost for owner famers. The total cost per hectare for Boro rice cultivation was estimated at Tk. 87847 for the owner farmer, Tk. 87360 for the cash tenant, Tk. 85098 for the input-output share type tenant and Tk. 85094 for the only output share tenant. The per hectare average yield was the highest for the owner farmer (6926 $\mathrm{kg}$ ) followed by cash tenant $(6909.2 \mathrm{Kg})$, fifty-fifty inputoutput share tenant $(6438 \mathrm{Kg})$ and only output share tenant $(6433.2 \mathrm{Kg})$.

Table 1. Demographic characteristics of the participants $(n=120)$

\begin{tabular}{|c|c|c|c|c|c|}
\hline \multirow[b]{2}{*}{ Particular characteristics } & \multicolumn{5}{|c|}{ Tenant type } \\
\hline & $\begin{array}{l}\text { Only output } \\
\text { share }\end{array}$ & $\begin{array}{l}\text { Fifty-fifty input- } \\
\text { output share }\end{array}$ & $\begin{array}{l}\text { Cash } \\
\text { tenant }\end{array}$ & Owner & Average \\
\hline Respondent's age (years) & 48.1 & 46.8 & 51.25 & 51.15 & 49.33 \\
\hline Education (years of schooling) & 5.9 & 6.95 & 6.9 & 10.58 & 7.58 \\
\hline Agriculture as a main occupation (\%) & 25 & 30 & 50 & 22.50 & 32 \\
\hline Credit received by the farmers $(\%)$ & 25 & 20 & 20 & 22.50 & 21 \\
\hline Extension service received by the farmers $(\%)$ & 20 & 15 & 7.5 & 22.5 & 16 \\
\hline Time of involvement with land tenure system (years) & 14.35 & 12.55 & 16.68 & 0 & 10.89 \\
\hline Farm size (decimals) & 258.05 & 277.2 & 304.5 & 229.95 & 267.43 \\
\hline No. of sample & 20 & 20 & 40 & 40 & 120 \\
\hline
\end{tabular}

Table 2. Per hectare cost and return of Boro rice production (in BDT)

\begin{tabular}{|c|c|c|c|c|c|c|c|c|}
\hline \multirow{2}{*}{ Items } & \multicolumn{2}{|c|}{ Owner farmer } & \multicolumn{2}{|c|}{ Cash tenant } & \multicolumn{2}{|c|}{$\begin{array}{l}\text { Fifty-fifty input-output } \\
\text { share type tenant }\end{array}$} & \multicolumn{2}{|c|}{$\begin{array}{l}\text { Only output share } \\
\text { type tenant }\end{array}$} \\
\hline & $\begin{array}{r}\text { Quantity } \\
\text { (Kg/ha) }\end{array}$ & Cost/ha & $\begin{array}{r}\text { Quantity } \\
\text { (Kg/ha) }\end{array}$ & $\begin{array}{r}\text { Cost } \\
\text { /ha }\end{array}$ & $\begin{array}{r}\text { Quantity } \\
\text { (Kg/ha) }\end{array}$ & Cost /ha & $\begin{array}{r}\text { Quantity } \\
\text { (Kg/ha) }\end{array}$ & Cost /ha \\
\hline Labour cost (Tk./ha) & & 26176 & & 25842 & & 25064 & & 24719 \\
\hline Seed cost (Tk./ha) & 14.70 & 3444 & 14.87 & 3388 & 14.84 & 3435 & 14.87 & 3388 \\
\hline Tractor cost (Tk./ha) & & 8628 & & 8636 & & 8612 & & 8654 \\
\hline Irrigation cost (Tk./ha) & & 8738 & & 8931 & & 8749 & & 8867 \\
\hline Fertilizer cost (Tk./ha) & & & & & & & & \\
\hline Urea & 265.76 & 4783 & 261.58 & 4708 & 248.78 & 4478 & 242.18 & 4359 \\
\hline TSP & 171.41 & 4285 & 164.69 & 4117 & 157.95 & 3948 & 164.26 & 4106 \\
\hline MP & 86.77 & 1475 & 83.78 & 1424 & 78.89 & 1341 & 78.02 & 1318 \\
\hline Gypsum & 43.12 & 431 & 45.32 & 453 & 45.11 & 451 & 44.72 & 447 \\
\hline Manure & & 6789 & & 6538 & & 6032 & & 6136 \\
\hline Insecticide & & 3829 & & 4054 & & 4459 & & 4539 \\
\hline Total variable cost (Tk.) & & 68581 & & 68094 & & 66573 & & 66569 \\
\hline Total fixed cost* & & 19266 & & 19266 & & 18525 & & 18525 \\
\hline Total cost (Tk.) & & 87847 & & 87360 & & 85098 & & 85094 \\
\hline Average yield $(\mathrm{Kg})$ & & 6926 & & 6909.2 & & 6438 & & 6433.2 \\
\hline Total return (Tk.) & & 115499 & & 115298 & & 107501 & & 107250 \\
\hline Net return (Tk.) & & 27652 & & 27938 & & 22403 & & 22156 \\
\hline Benefit Cost Ratio & & 1.31 & & 1.32 & & 1.26 & & 1.26 \\
\hline
\end{tabular}


Table 3. Productivity and profitability differences among tenure categories

\begin{tabular}{|c|c|c|c|c|}
\hline \multirow[b]{2}{*}{ Types of farmer } & \multicolumn{2}{|c|}{ Productivity } & \multicolumn{2}{|c|}{ Profitability } \\
\hline & $\begin{array}{l}\text { Productivity } \\
\text { difference }\end{array}$ & $\begin{array}{c}\text { t- } \\
\text { value }\end{array}$ & $\begin{array}{c}\text { Profitability } \\
\text { difference }\end{array}$ & $\begin{array}{c}\text { t- } \\
\text { value }\end{array}$ \\
\hline Owner farmer versus fifty-fifty input-output share tenant & 488.18 & 9.58 & 5202.69 & 4.24 \\
\hline Owner farmer versus only output share tenant & 493.08 & 8.03 & 5580.29 & 3.89 \\
\hline Owner farmer versus cash tenant & 17.14 & 0.45 & 158.94 & 0.14 \\
\hline Cash tenant versus fifty-fifty input-output share tenant & 471.04 & 8.59 & 5361.63 & 3.62 \\
\hline Cash tenant versus only output share tenant & 475.94 & 7.36 & 5739.24 & 3.46 \\
\hline Fifty-fifty input-output share versus only output share tenant & 4.91 & 0.06 & 377.60 & 0.20 \\
\hline
\end{tabular}

Total return per hectare was calculated by multiplying the total yield of Boro rice produced by the farm-gate price during the harvest. Total return per hectare calculated Tk. 115499 for the owner farmer which was highest among other categories and Tk. 115298, Tk. 107501, Tk. 107250 for cash tenant, fifty-fifty input-output share tenant and only output share tenant respectively. Table 2 also shows that net returns for the owner farmer, cash tenant, fifty-fifty input-output share tenant and only output share type tenant which was Tk. 27652, Tk. 27938, Tk. 22403, Tk. 22156 respectively. Net return found highest in case of cash tenant and the net return of owner farmers was very much parallel to cash tenants. The BCR found highest for cash tenant which was 1.32 and the BCR of owner farmer was very close to cash tenant which was 1.31 , both input-output share type tenant and only output share type tenant had BCR of 1.26. These findings are consistent with Islam et al., (2017) where they found overall BCR of rice production was 1.25 in the southern coastal areas of Bangladesh. So, overall the Boro rice cultivation was profitable for all kind of tenure system but in case of cash tenant and owner farmer, it was more profitable than any other category. Therefore, we can conclude that owner famers and cash tenants were approximately equivalent productive and profitable.

\section{Productivity and Profitability Difference as Per Tenure System}

To examine whether any significant difference exists in productivity and profitability among tenure categories, $\mathrm{t}$ test had been performed which shown in Table 3. Productivity difference between categories expressed in $\mathrm{kg}$ and BDT has used to express the profitability difference between tenure categories. From the result of productivity difference, it was found that mean productivity difference between owner farmer and fifty-fifty input-output share tenant was $488.18 \mathrm{Kg}$ which was significant at $1 \%$ level. Productivity found significantly higher for owner farmer compared to only output share tenant, cash tenant compared to fifty-fifty input-output share tenant. Owner farmer and cash tenant had significantly higher productivity than shared cropping arrangement.

Results found that the mean profitability difference between owner farmer versus fifty-fifty input-output share tenant was Tk. 5202.69 which was significant at $1 \%$ level. The highest profitability difference between cash tenant versus only output share tenant which was Tk. 5739.24. Profitability difference was also significant $1 \%$ level regarding owner farmer versus only output share tenant and cash tenant versus fifty-fifty input-output share tenant. However, owner farmer and cash tenant were more profitable than those who were sharing input and output. The owner farmers do not have to pay others and cash tenant farmers pay a certain amount of cash before production season so they can utilize input as much as they want to boost up the production. The higher production leads them to attain higher profit. In contrast, sharecropper have an agreement on sharing inputs and outputs, the higgling issue of inputs share and output share reluctant them to utilize sufficient inputs resulting less production hence less profit.

\section{Efficiency and Efficiency Differences as Per Tenure Categories}

Amid claims about the potential disincentive effects and efficiency losses of sharecropping, combined with the inclusion of socio-economic variable and diffusion of the practice in much of the developing world, make share tenancy one of the most arguable issue. However, to estimate the efficiency, Boro rice production had been explained by nine variables namely, labor, seed, urea, TSP, MOP, gypsum, manure, insecticide/pesticide and irrigation. These estimated parameters following the maximum likelihood estimation method of the CobbDouglas production frontier have been shown in Table 4. Result revealed that all the explanatory variables have a significant effect on production volume excluding labor, seed, urea and insecticides/pesticides. The estimated value of the coefficient of TSP was positive which was significant at $1 \%$ level. This means, on average the Boro rice production might be increased if the farmers used more TSP fertilizer in their field since applying TSP in the rice field augment the production. The estimated value of the coefficient of MOP was negative but significant at $1 \%$ level, which means if the farmer overuse MOP fertilizer, the production of Boro rice might be decreased. The value of the coefficient of gypsum and manure also had significant positive effect on rice production. Therefore, the farmers of the study area may increase the application of TSP, gypsum and manure to boost up Boro rice production with the existing technology since those had a significant positive effect on Boro rice production. The estimated value of the coefficient of irrigation was negative $(-0.091)$ but significant at $1 \%$ level. That means the more irrigation applied in the rice field, the less production of Boro rice because the panicle of rice may get perished in waterlogging condition though it may have significant positive effect on rice production at the time of extreme drought. Boro rice is grown in the very low-lying areas with residual water from the wet season and irrigated manually using surface water in times of water shortage. Farmers had to irrigate their rice plots whenever required 
at the time of drought by purchasing water from hired Shallow Tube-Wells (STWs) and had to pay higher charge for irrigation water that's why they were very optimistic using excess irrigation water though Boro is the dry-season irrigated rice. Besides, the summers are much rainier than the winters in the study area, so farmers required less irrigation for rice production. In addition, a significant number of farmers in the study area grew drought tolerant variety like BRRI dhan 55 in the Boro season. These were the most possible reasons for negative effect of irrigation on Boro rice production in the study area.

Inefficiency model was used to determine the contribution of socioeconomic variables to the technical inefficiency of Boro rice production has been shown in Table 5. The inefficiency function has been explained by five variables namely, age, education, time duration with the land tenure system, credit receive, extension service receives. It was found that Boro rice farmers with young age, time duration with land tenure system and credit receiving are less likely to be efficient in rice production. The coefficient of age was negative and significant at $1 \%$ level. It implies that the technical inefficiency decreases as the age of farmers increases. The older farmers were relatively more efficient than that of younger's because they are more familiar with production practices and have the ability to manage their inputs more efficiently and they are more risk averter than their younger counterparts. The sign of the coefficient of time duration with involvement land tenure system was positive and significant at $1 \%$ level. It means that technical efficiency increases with an increase in time duration involving with land tenure system. So the tenant farmers who involved with land tenure system for a long period are technically more efficient than the farmers who are involved with tenure system for a short period of time because over time farmers were able to use inputs efficiently. The estimated value of the coefficient of credit received was significant at $5 \%$ level that means farmers who received credit from external sources were more efficient than those who did not receive credit because farmers who received credit could use sufficient inputs whenever needed in the production process.

Technical efficiency scores have been presented in figure 1 as per tenure system. It was revealed that cash tenants (0.97) and owners (0.97) were equally efficient than only output share type tenant $(0.90)$ and fifty-fifty input-output share type tenant (0.91) which was supported by the Marshallian inefficiency theory. Marshallian inefficiency theory described that owner and fixed-rate tenants are efficient rather than sharecroppers. Sharecroppers are inefficient. Because of secured property rights, the owner farmer gave sufficient effort to increase their efficiencies. On the other hand, there was a misdoubt among sharecroppers to miss out land that was rented from the landowner. So the sharecropper did not use inputs efficiently, did not invest in land development. However, the mean efficiency score of all farmers was 0.95 that means they still have chance to get potential yield by proper use and management of inputs. This result is consistent with Khan et al. (2010) where they found technical efficiency of Boro rice producer was 0.95 in the Jamalpur district of Bangladesh.

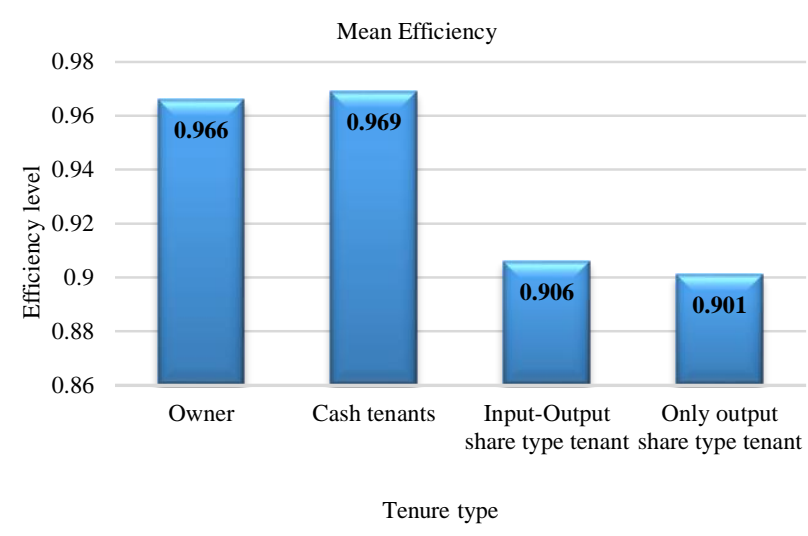

Figure 1. Mean efficiency of different tenant farmers and owners

Table 4. Maximum likelihood estimates of the parameters of Cobb-Douglas stochastic frontier production function

\begin{tabular}{l|cc}
\hline \multicolumn{1}{c|}{ Variable } & Coefficient & SE \\
\hline Labor & 0.017 & 0.023 \\
Seed & -0.006 & 0.037 \\
Urea & -0.043 & 0.034 \\
TSP & $0.115^{* * *}$ & 0.046 \\
MOP & $-0.046 * * *$ & 0.018 \\
Gypsum & $0.042^{* *}$ & 0.021 \\
Manure & $0.056^{* * *}$ & 0.019 \\
Insecticide/Pesticide & -0.011 & 0.012 \\
Irrigation & $-0.091 * * *$ & 0.006 \\
Constant & $5.257 * * *$ & \\
\hline
\end{tabular}

SE: Standard Error, ***, ** and * indicate significant at 1\%, 5\% and $10 \%$ level, respectively.

Table 5. Estimating the inefficiency model

\begin{tabular}{l|cc}
\hline \multicolumn{1}{c|}{ Variable } & Coefficient & SE \\
\hline Age (Years) & $-0.006 * * *$ & 0.001 \\
Education (Years of schooling) & 0.006 & 0.004 \\
Time duration involvement & $-0.003^{* * *}$ & 0.001 \\
with land tenure system (Years) & & \\
Credit receive (1 if credit & $-0.037 * *$ & 0.017 \\
received, 0 otherwise) & & \\
Extension service receive (1 if & -0.016 & 0.021 \\
service received, 0 otherwise) & 0.351 & 0.060 \\
Constant & \multicolumn{2}{|c}{213.37} \\
\hline Log-likelihood value & \multicolumn{2}{|c}{0.94464} \\
Mean technical efficiency & \\
\hline
\end{tabular}

SE: Standard Error, ${ }^{* * *}, * *$ and $*$ indicate significant at $1 \%, 5 \%$ and $10 \%$ level, respectively.

Table 6. Efficiency differences among tenure categories

\begin{tabular}{l|cc}
\multicolumn{1}{c|}{ Types of farmer } & $\begin{array}{c}\text { Efficiency } \\
\text { difference }\end{array}$ & $\begin{array}{c}\mathrm{t}- \\
\text { value }\end{array}$ \\
\hline $\begin{array}{l}\text { Owner farmer versus input-output } \\
\text { share tenant }\end{array}$ & 0.06 & 7.01 \\
\hline $\begin{array}{l}\text { Owner farmer versus only output } \\
\text { share tenant }\end{array}$ & 0.07 & 7.23 \\
\hline Owner farmer versus cash tenant & 0.003 & 0.58 \\
\hline $\begin{array}{l}\text { Cash tenant versus input-output } \\
\text { share tenant }\end{array}$ & 0.06 & 7.98 \\
\hline $\begin{array}{l}\text { Cash tenant versus only output } \\
\text { share tenant }\end{array}$ & 0.07 & 8.13 \\
\hline $\begin{array}{l}\text { Input-output share versus only } \\
\text { output share tenant }\end{array}$ & 0.01 & 0.44 \\
\hline
\end{tabular}


To examine whether any difference in efficiency level among tenure system, $\mathrm{t}$-test has been preferred which shown in Table 6. It was found that the efficiency difference between owner farmer versus input-output share tenant is 0.06 and it was significant at $1 \%$ level. The efficiency difference between owners versus only output share type tenant was 0.07 and it was also significant at $1 \%$ level. Efficiency difference also significant at $1 \%$ level regarding cash tenant versus input-output share tenant, cash tenant versus only output share tenant. So, it was observed that significant efficiency difference might exist comparing owner farmer or cash tenant with other categories because both were less in efficient than sharecroppers.

\section{Conclusion and Recommendations}

This study assessed the different land tenure systems in Bangladesh and its effect on productivity, profitability and efficiency on Boro rice production. In this paper, the stochastic frontier production function was used to determine the efficiency, profitability of Boro rice farmers was measured according to per hectare by net return and benefit-cost ratio (BCR). Productivity was highest for the owner farmer category. The results of benefit-cost analysis and net return indicated that the value of BCR and net return for cash tenant and owner farmers were higher than others because they had freedom to inputs use in the production process while sharecroppers were very much supervised by the landlord for efficient use of land and other production inputs. The inputs like TSP, gypsum and manure had a significant positive effect on production while MOP and irrigation had a significant negative effect on production. Results indicated that the farmer's age, time duration involvement with land tenure system and credit received were the most important socioeconomic determinants of inefficiency. Results also revealed that cash tenant and owner farmer are more efficient than sharecroppers, this result also supported by the efficiency scores of different categories tenants. The results of efficiency differences among the tenure categories indicated that there was a significant efficiency difference between owner versus input and output share tenant, owner versus only output share tenant, cash tenant versus input and output share tenant and cash tenant versus only output share tenant. However, among all tenant system owner and cash tenants get benefit and economically in safer position. There are important policy implications that can be derived from this study:

- If we could provide microcredit to the farmers so that they can get the credit facilities to attain cash tenancy mode of production in replace of share crop tenancy.

- Special attention should be given to protect the rights of sharecroppers. Therefore, the existing sharing system between landowner and tenants should be uniform and modified throughout Bangladesh.

- If an appropriate mix of land reform and agricultural development policies were adopted, Bangladesh could meet its food needs as well as ensure rural employment in agriculture.

\section{Conflict of Interest}

The authors declare that there is no conflict of interests regarding the publication of this paper.

\section{Acknowledgement}

The first author thankfully acknowledges the Ministry of Science and Technology of the Government of People's Republic of Bangladesh for funding this research project and also grateful to the respondents who shared their valuable information.

\section{References}

Agricultural Census. 2008. Bangladesh Bureau of Statistics. Statistics and Information Division, Ministry of Planning, Governments People's Republic of Bangladesh, Dhaka.

Ahmed S. 2011. Determinants of the choice of agricultural tenancy contracts in rural Bangladesh. (No. 422-201626848).

Aigner DC, Lovell AK, Schmidt PJ. 1977. Formulation and Estimation of Stochastic Frontier Production Function Models. Journal of Econometrics, 6(1): 21-37.

Ali H. 2000. Impact of land tenurial arrangements on cost return and household income of paddy growing farmers of sadar upazila in Mymensingh district. MS Thesis, Department of Agricultural Economics, Bangladesh Agricultural University, Mymensingh.

Arindam L, Kuri PK. 2012. Differences in resource allocation under alternative tenurial contracts and its explanations: evidence from rural West Bengal, India. Trends in Agricultural $\quad$ Economics, 5(1): 13-22. doi.org/10.3923/tae.2012.13.22.

Aryal JP. 2010. Cast discrimination, Land tenure, and natural resources management in Nepal PhD Thesis. Department of Economics and Resource Management, Norwegian University of Life Science.

Battese GE, Coelli TJ. 1993. A Stochastic Frontier Production Function Incorporating a Model for Technical efficiency effect. Working paper in Econometrics and Applied Statistics. No. 70, Department of Econometrics, University of New England, Australia.

Battese GE, Coelli TJ. 1995. A Model for Technical Efficiency Effects in a Stochastic Production Function for Panel Data. Empirical Economics, 20(2): 325-332. doi.org/10.1007/ BF01205442

BBS (Bangladesh Bureau of Statistics). Year Book of Agricultural Statistics 2018. Statistics and Information Division, Ministry of Planning, Government of the people's Republic of Bangladesh, Dhaka.

Bhownick BC, Saikia RS, Ihazarika C. 2003. A study on the impact of tenancy system on resource use and productivity in Jorhat district of Asam. National Bank for Agriculture and Rural Development, Occasional paper- 27, Mumbai, India.

Coelli TJ, Battese GE. 1996. Identification of Factors Which Influence the Technical Efficiency of Indian Farmers. Australian Journal of Agricultural Economics, 40(2): 103128. doi.org/10.1111/j.1467-8489.1996.tb00558.x

Coelli TJD, Rao SP, Battese GE. 1998. An Introduction of Efficiency and Productivity Analysis. Springer Science \& Business Media, pp. 349, New York, USA.

Farrell MJ. 1957. The measurement of Productive Efficiency. Journal of the Royal Statistical Society, 120(3): 253-290. doi.org/10.2307/2343100

Jabbar MA. 1978. The land tenure system in Bangladesh. In: Agrarian Structure and Rural Change. Ministry of Agriculture, Government of the people's Republic of Bangladesh, pp.61-87, Dhaka, Bangladesh. 
Hayami Y, Otsuka K. 1993. The economics of contract choice: an agrarian perspective. Clarendon Press. ISBN 0198283784.

Islam DMN. 2012. Impact on new technology on sharecropping in Bangladesh. The $18^{\text {th }}$ Biennial Conference Bangladesh Economic Association, Dhaka.

Islam Z, Begum R, Sharmin S, Khan MA. 2017. Profitability and Productivity of Rice Production in Selected Coastal Area of Satkhira District in Bangladesh. International Journal of Business, Management and Social Research, 3(1): 148-153. doi.org/10.18801/ijbmsr.030117.17.

Khan MA, Huda FA, Alam A. 2010. Farm Household Technical Efficiency: A Study on Rice Producers in Selected Areas of Jamalpur District in Bangladesh. European Journal of Social Sciences, 14 (2): 262-271

Khan T. 2008. An economic analysis of the impact of land tenure system on Boro paddy production in a selected area of Mymensingh district. MS Thesis, Department of Agricultural Economics, Bangladesh Agricultural University, Mymensingh.

Khatun MM, Saha SM, Khan MA, Hossain ME. 2020. Farmers' Supply Response and Perception of Rice Procurement Program in Bangladesh. Future of Food: Journal on Food, Agriculture and Society, 8(3).

Marara J. 2007. Regional differences regarding land tenancy in rural Rwanda, with special references to share cropping in a coffee producing area Shnichi Takaeuchi. African study Monographs, 35: 11-138. doi.org/10.14989/68488.

Meeusen W, Broeck VD. 1977. Efficiency Estimation from Cobbdouglas Production Functions with Composite Error. International Economic Review, 18: 435-444. doi.org/ $10.2307 / 2525757$

Mondal RK. 2005. An economic of input use and productivity of HYV Boro rice producing farms by tenancy in some selected areas of Gaibandha district. MS Thesis, Department of Agricultural Economics, Bangladesh Agricultural University, Mymensingh.
Nasrin M. 2011. Land tenure system and food security in some selected areas of Mymensingh district. MS Thesis, Department of Agricultural Economics, Bangladesh Agricultural University, Mymensingh.

Otsuka K. 2007. Efficiency and Equity Effects of Land Markets. In Handbook of Agricultural Economics, 3: 2671-2703. doi.org/10.1016/S1574-0072(06)03051-9.

Otsuka K, Hayami Y. 1988. Theories of Share Tenancy: A Critical Survey. Economic Development and Cultural Change, 37(1): 32-68. doi.org/10.1086/451707.

Rahman S. 2010. Detriments of agricultural land rental market transactions in Bangladesh. Land use policy, 27 (3): 957-964. doi.org/10.1016/j.landusepol.2009.12.009

Reiersen J. 2001. Social status and work incentives in sharecropping: The case of rural Bangladesh. Vest fold college publication series, paper 9-2001.

Singh N. 1989. Theories of Sharecropping. In: Bardhan P (1991). The economic theory of agrarian institutions. New York, Oxford University Press. ISBN-13: 9780198287629 (Print)

Taslim MA, Ahmed FU. 1992. An Analysis of Land Leasing in Bangladesh Agriculture. Economic Development and Cultural Change, 40(3): 615-628. doi.org/10.1086/451963

Tenaw S, Islam KMZ, Parviainen T. 2009. Effects of land tenure and property rights on agricultural productivity in Ethiopia, Namibia and Bangladesh. Department of Economics and Management, University of Helsinki, Paper No. 33.

Uddin AMF, Haque JT. 2009. Agrarian transition and livelihood of the rural poor: The agricultural land market publication of Unnayan Onneshan - The Innovators.

Zaman M. 2002. Resource productivity and adoption of modern technology by tenancy: A study of HYV Boro production in a selected area of Dinajpur district. MS Thesis, Department of Agricultural Economics, Bangladesh Agricultural University, Mymensingh. 